\title{
EFFECT OF NISIN AS A BIOPRESERVATIVE ON SHELF LIFE OF PASTEURIZED MILK
}

\author{
ZEINAB M. ABD-EL HAMEED and WALAA M.A. ELSHERIF \\ Animal Health Research Institute, Agriculture Research Center (ARC), Food Hygiene, Assiut Regional Lab., Egypt.
}

Received: 30 December 2018; Accepted: 13 January 2019

\begin{abstract}
In this study, the bacteriocin nisin at varius concentrations (50, 100 and $200 \mathrm{IU} / \mathrm{ml}$ ) was studied as a biopreservative to extend the shelf life of pasteurized milk. A minimum of one week extension in shelf life was obtained for pasteurized milk at refrigerator temperature storage. Higher concentration of nisin $(200 \mathrm{IU} / \mathrm{ml})$ showed no different effect than the lower one. The effect of nisin added on microbiological quality (standard plate count (SPC), psychrotrphs, proteolytic and thermophilic counts) of pasteurized milk studied and showed significant decrease in all of them than control samples (free from nisin). Also, nisin reduced the development of acidity so extend the shelf life of examined samples. The antibacterial effect of nisin studied on Staphylococcus aureus (Staph. aureus) inoculated in pasteurized milk and the result clarified complete inhibition of Staph. aureus at $6^{\text {th }}$ day. Palatability of addition of different concentrations of nisin was also discussed. Nisin had the ability to control the spoilage bacteria so could be control the acidity of products and have antibacterial effect against pathogenic bacteria so act as a principal, safe and natural preservative for pasteurized milk.
\end{abstract}

Key words: Nisin; Biopreservative; Staph. aureus; Pasteurized milk; Psychrotrophs; Thermophilic and Proteolytic bacteria.

\section{INTRODUCTION}

Pasteurization is the simplest means of extending the keeping quality of milk without impairing the sensory and nutritional attributes. However, there is a requirement to further extend the shelf life of pasteurized milk for the convenience of the consumers and to provide additional protection against temperature variations during transportation and storage. Utilization of Bacteriocins alone, or combined with other treatments, could represent a promising advance for the microbiological safety and maintenance of sensory properties in milk and milk products (Lopez and Belloso, 2008). Exploitation of bacteriocin such as nisin as a bio preservative is a newer approach to achieve extended shelf life in regions with inadequate refrigeration facilities (Radha, 2014).

Nisin is a bacteriocin or natural antibacterial peptide with 34 amino acid residues produced by the bacterium Lactococcus lactis that is used as a food preservative for dairy and meat products. Nisin inhibits pathogenic food borne bacteria and many other Gram-positive food spoilage microorganisms

Corresponding author: WALAA M.A. ELSHERIF

E-mail address: sch_qana@yahoo.com

Present address: Animal Health Research Institute, Food Hygiene, Assiut Regional Lab., Egypt.
(Kindrachuk et al., 2012 and Gharsallaoui et al., 2016). The commercial nisin has been recognized as a safe food preservative by the joint Food and Agriculture Organisation and World Health Organisation (FAO/WHO) and in 1988 by the US Food and Drug Administration (FDA) (FDA /HHS, 1988 and Thomas et al., 2000) and it permitted and widely used in the food industry as a safe and natural food preservative in over 50 countries around the world (Pimentel-Filho et al., 2014).

Nisin has more than one mechanisms of antimicrobial action depending on several factors such as structural properties of target bacteria and exhibits antimicrobial activity against many species of Gram positive pathogens responsible for bovine mastitis but not Gram negative bacteria due to their outer membrane barriers. Antibacterial mechanisms of nisin may be due to passage through cell wall and interaction with lipid II (Wiedemann et al., 2004 and Kramer et al., 2008). In addition, both nisin A (and its natural variant nisin Z) have been incorporated into a number of products devoted to restricting or treating bovine mastitis (Sears et al., 1992 and Wu et al., 2007). Notably, in addition to being effective against planktonic cells of multi-drug resistant staphylococci (Dosler and Gerceker, 2011 and Okuda et al., 2013), 
Staph. aureus, an opportunistic pathogen, is the leading cause of a broad range of human infections and associated with food poisoning (Argudin et al., 2010). It is a growing concern worldwide and is of concern in terms of both foodborne disease and food spoilage (Loir et al., 2003).

So, the present study will investigate the effect of Nisin as a bio preservative on keeping quality of pasteurized milk which manipulated in Assiut city, Egypt. Also, clarifying the antibacterial activity of nisin on Staph. aureus.

\section{MATERIALS AND METHODS}

\section{1-Concentrations of nisin in pasteurized milk:}

Forty pasteurized milk samples was purchased from a retail market and examined by phosphatase test to confirm the efficacy of pasteurization (Fasken and McClure, 1940) then treated with different concentrations of nisin $(0,50,100$ and $200 \mathrm{IU} / \mathrm{ml})$ divided into 10 samples for each. The samples were stored at refrigerator temperature $\left(4 \pm 2{ }^{\circ} \mathrm{C}\right)$ and examined bacteriologically every 3 days and examined for $\mathrm{pH}$ by $\mathrm{PH}$ meter and clot on boiling test for freshness detection (Wirjantoro and Lewis, 1996 and Radha, 2014).

\section{2- Microbiological analysis:}

All samples examined for:

Total bacterial counts: was done according to APHA, (1998).

Total psychrotrophic count: was done according to Sharma et al. (2007).

\section{Enumeration of total thermophiles:}

One $\mathrm{ml}$ of the sample and its decimal dilutions was plated using milk plate count agar (MPCA) and incubated at $55^{\circ} \mathrm{C}$ for $48 \mathrm{~h}$ as described by Frank and Yousef (2004).

Total Proteolytic counts: adopted according to APHA, (1992).

\section{3 - Bacterial suspension inoculation:}

Reference strain of Staph. aureus was used (reference strain from Animal Health Research Institute, Giza with code NCTC 7447 / ATCC 6538). Staph. aureus was grown in Tryptic Soy
Broth for $24-48 \mathrm{~h}$ at $37^{\circ} \mathrm{C}$. Then the suspension was adjusted to the turbidity of a $0.5 \mathrm{McF}$ arland standard by adding sterile saline to achieve a strain concentration of approximately $1 \times 10^{5}$ colony forming units $/ \mathrm{ml}$ (Gentilini et al., 2000 and Bennett and Lancette, 2016).

\section{4 - Antibacterial properties of nisin:}

Pasteurized milk was purchased from a retail market. One $\mathrm{ml}$ of previously prepared Staph. aureus suspension mixed with $100 \mathrm{ml}$ of pasteurized milk and divided into suitable sterile jars, nisin was add at concentrations 50, 100 and $200 \mathrm{IU} / \mathrm{ml}$ and another positive control jars without nisin (Radha, 2014). Control jars (free from strain suspension and nisin as a negative control) was also stored. The jars were stored at refrigerator temperature $\left(5 \pm 2{ }^{\circ} \mathrm{C}\right)$. The inoculated jars were examined bacteriologically for the count of Staph. aureus using Baird-Parker media at time zero and, every 3 days until the end of experiment and detected by the $\mathrm{pH}$ was measured in the control jars by using $\mathrm{pH}$ meter and clot on boiling test. (Prado-Acosta et al., 2010).

\section{5 - Sensory evaluation:-}

Control pasteurized milk jars (free from the previous microorganism but inoculated with nisin at concentrations of 50, 100 and $200 \mathrm{IU} / \mathrm{ml}$, respectively) were prepared as previously mentioned and each was subjected to the previous treatments. Thirty consumers were selected in teams of different ages, sex (15 females and 15 males), and education to taste the trials. The perception of consumers toward samples with various conc. of nisin was studied with respect to two different attributes (flavor and palatability) (Radha, 2014). The level of agreement was scored as strongly agree (SA), agree (A), disagree (D), and strongly disagree (SD) according to Nelson and Torut (1981).

\section{6 - Statistical analysis:-}

Sensory evaluation was compared by entered the data into the Microsoft Excel Spreadsheet. Data obtained in this study were analyzed by using one and two way classification analysis of variance test to study the preservative effect of nisin on pasteurized milk samples. Mean and standard error were estimated for each parameter and ANOVA test for detection significant or not results in comparing with control results. $\mathrm{P}$ values lower than 0.05 were considered significant. 


\section{RESULTS}

Table 1: Effect of incorporation of different concentrations of Nisin on the Clot on boiling test of pasteurized milk stored at $4^{\circ} \mathrm{C}$.

\begin{tabular}{lllll}
\hline \multirow{2}{*}{$\begin{array}{l}\text { Storage period on } \\
\text { days }\end{array}$} & \multicolumn{4}{l}{ Nisin concentration IU/ml } \\
\cline { 2 - 5 } & Control & 50 & 100 & 200 \\
\hline 0 & $-v e$ & $-v e$ & $-v e$ & $-v e$ \\
\hline 3 & $-v e$ & $-v e$ & $-v e$ & $-v e$ \\
\hline 9 & $-v e$ & $-v e$ & $-v e$ & $-v e$ \\
\hline 12 & $-v e$ & $-v e$ & $-v e$ & $-v e$ \\
\hline 15 & $+v e$ & $-v e$ & $-v e$ & $-v e$ \\
\hline
\end{tabular}

Table 2: Effect of incorporation of different concentrations of Nisin on the $\mathrm{pH}$ of pasteurized milk stored at $4^{\circ} \mathrm{C}$.

\begin{tabular}{lcccc}
\hline \multirow{2}{*}{$\begin{array}{l}\text { Storage } \\
\text { days }\end{array}$} & period & on & \multicolumn{4}{c}{ Nisin concentration IU/ml } \\
\cline { 2 - 5 } & Control & 50 & 100 & 200 \\
\hline 0 & $6.31 \pm 0.08$ & $6.26 \pm 0.08$ & $6.31 \pm 0.08$ & $6.31 \pm 0.08$ \\
\hline 3 & $6.01 \pm 0.08$ & $6.16 \pm 0.08$ & $6.35 \pm 0.08$ & $6.32 \pm 0.07$ \\
\hline 6 & $5.90 \pm 0.08$ & $6.05 \pm 0.08$ & $6.32 \pm 0.08$ & $6.37 \pm 0.07$ \\
\hline 9 & $5.3 \pm 0.09$ & $6.14 \pm 0.08$ & $6.24 \pm 0.08$ & $6.40 \pm 0.07$ \\
\hline 12 & $4.10 \pm 0.09$ & $5.93 \pm 0.07$ & $5.55 \pm 0.06$ & $5.26 \pm 0.07$ \\
\hline 15 & $3.51 \pm 0.09$ & $5.10 \pm 0.06$ & $5.25 \pm 0.06$ & $5.11 \pm 0.07$ \\
\hline
\end{tabular}

Means \pm SE are averages of Ten replications significant: $P<0.05$

Table 3: Effect of incorporation of different concentrations of Nisin on the Standard plate count (SPC) of pasteurized milk stored at $4{ }^{\circ} \mathrm{C}$

\begin{tabular}{|c|c|c|c|c|}
\hline \multirow{3}{*}{$\begin{array}{l}\text { Storage } \\
\text { period } \\
\text { days }\end{array}$} & \multicolumn{4}{|c|}{ Nisin concentration IU/ml } \\
\hline & Control & 50 & 100 & 200 \\
\hline & \multicolumn{4}{|c|}{ Standard plate count $\mathrm{CFU} / \mathrm{ml}$} \\
\hline $\mathbf{0}$ & $7.15 \times 10^{2} \pm 3.8 \times 10$ & $7.10 \times 10^{2} \pm 5.9 \times 10$ & $6.53 \times 10^{2} \pm 5.1 \times 10$ & $6.53 \times 10^{2} \pm 5.9 \times 10$ \\
\hline 3 & $9.55 \times 10^{2} \pm 1.1 \times 10^{2}$ & $8.2 \times 10^{2} \pm 5.1 \times 10$ & $5.54 \times 10^{2} \pm 3.9 \times 10$ & $5.11 \times 10^{2} \pm 3.7 \times 10^{*}$ \\
\hline 6 & $2.05 \times 10^{3} \pm 2.2 \times 10^{2}$ & $8.43 \times 10^{2} \pm 2.3 \times 10 * * *$ & $4.40 \times 10^{2} \pm 4.3 \times 10 * * *$ & $4.64 \times 10^{2} \pm 2.0 \times 10 * * *$ \\
\hline 9 & $1.14 \times 10^{4} \pm 3.9 \times 10^{2}$ & $7.72 \times 10^{2} \pm 5.6 \times 10 * *$ & $3.24 \times 10^{2} \pm 8.4 \times 10 * *$ & $2.52 \times 10^{2} \pm 3.9 \times 10 * *$ \\
\hline 12 & NT & $6.72 \times 10^{2} \pm 4.6 \times 10$ & $5.15 \times 10 \pm 3.4 \times 10$ & $5.52 \times 10 \pm 1.8 \times 10$ \\
\hline 15 & NT & $5.62 \times 10 \pm 2.3 \times 10$ & $3.21 \times 10 \pm 1.4 \times 10$ & $3.32 \times 10 \pm 0.47 \times 10$ \\
\hline
\end{tabular}

NT: not tested *significant $* *$ moderate significant $* * *$ highly significant

Means \pm SE of Ten replications significant: $P<0.05$

*P value for tested concentrations of nisin in comparison with control was $<0.0001$ 
Table 4: Effect of incorporation of different concentrations of Nisin on the Psychrotrophs count of pasteurized milk stored at $4{ }^{\circ} \mathrm{C}$.

\begin{tabular}{lcccc}
\hline \multirow{2}{*}{$\begin{array}{l}\text { Storage } \\
\text { period } \\
\text { on days }\end{array}$} & Control & \multicolumn{5}{c}{ Nisin concentration IU/ml } \\
\cline { 2 - 5 } & \multicolumn{5}{c}{50} & 100 & 200 \\
\cline { 2 - 5 } & \multicolumn{4}{c}{ Count CFU/ml } \\
\hline 0 & $6.25 \times 10^{2} \pm 3.09 \times 10^{2}$ & $6.05 \times 10^{2} \pm 3.09 \times 10^{2}$ & $6.43 \times 10^{2} \pm 3.09 \times 10^{2}$ & $6.30 \times 10^{2} \pm 3.09 \times 10^{2}$ \\
\hline 3 & $2.38 \times 10^{3} \pm 4.6 \times 10^{2}$ & $5.68 \times 10^{2} \pm 3.1 \times 10^{2}$ & $9.7 \times 10 \pm 4.2 \times 10^{*}$ & $3.9 \times 10 \pm 1.5 \times 10^{*}$ \\
\hline 6 & $2.52 \times 10^{3} \pm 4.8 \times 10^{2}$ & $5.21 \times 10^{2} \pm 1.6 \times 10^{2}$ & $8.2 \times 10 \pm 3.6 \times 10^{* *}$ & $3.2 \times 10 \pm 1.3 \times 10^{* * *}$ \\
\hline 9 & $4.2 \times 10^{2} \pm 3.2 \times 10^{2}$ & $2.3 \times 10 \pm 1.8 \times 10$ & $1.9 \times 10 \pm 0.9 \times 10$ & $1.1 \times 10 \pm 0.6 \times 10$ \\
\hline 12 & $\mathrm{NT}$ & 00 & 00 & 00 \\
\hline 15 & $\mathrm{NT}$ & 00 & 00 & 00 \\
\hline
\end{tabular}

NT: not tested *significant **moderate significant ***highly significant

Means \pm SE of Ten replications significant: $P<0.05$

$* \mathbf{P}$ value for tested concentrations of nisin in comparison with control was $<0.0001$

Table 5: Effect of incorporation of different concentrations of Nisin on the Proteolytic count of pasteurized milk stored at $4{ }^{\circ} \mathrm{C}$.

\begin{tabular}{|c|c|c|c|c|}
\hline \multirow{3}{*}{$\begin{array}{l}\text { Storage } \\
\text { period } \\
\text { on days }\end{array}$} & \multicolumn{4}{|c|}{ Nisin concentration IU/ml } \\
\hline & Control & 50 & 100 & 200 \\
\hline & \multicolumn{4}{|c|}{ Count CFU/ml } \\
\hline $\mathbf{0}$ & $8.33 \times 10^{2} \pm 4.4 \times 10^{2}$ & $7.73 \times 10^{2} \pm 4.1 \times 10^{2}$ & $7.85 \times 10^{2} \pm 4.2 \times 10^{2}$ & $7.57 \times 10^{2} \pm 4.2 \times 10^{2}$ \\
\hline 3 & $8.69 \times 10^{2} \pm 4.5 \times 10^{2}$ & $5.35 \times 10^{2} \pm 2.8 \times 10^{2}$ & $5.48 \times 10^{2} \pm 3.1 \times 10^{2}$ & $3.16 \times 10^{2} \pm 1.8 \times 10^{2}$ \\
\hline 6 & $1.0 \times 10^{3} \pm 5.1 \times 10^{2}$ & $3.84 \times 10^{2} \pm 2.1 \times 10^{2}$ & $3.0 \times 10^{2} \pm 1.7 \times 10^{2}$ & $2.01 \times 10^{2} \pm 1.3 \times 10^{2}$ \\
\hline 9 & $3.22 \times 10^{3} \pm 5.2 \times 10^{2}$ & $7.56 \times 10 \pm 3.6 \times 10$ & $5.23 \times 10 \pm 2.4 \times 10$ & $4.02 \times 10 \pm 1.6 \times 10$ \\
\hline 12 & NT & $3.54 \times 10 \pm 1.2 \times 10$ & $1.5 \times 10 \pm 0.8 \times 10$ & 00 \\
\hline 15 & NT & 00 & 00 & 00 \\
\hline
\end{tabular}

NT: not tested

Means $\pm \mathrm{SE}$ of Ten replications

significant: $\mathrm{P}<\mathbf{0 . 0 5}$

Table 6: Effect of incorporation of different concentrations of Nisin on the Thermophilic count of pasteurized milk stored at $4{ }^{\circ} \mathrm{C}$.

\begin{tabular}{lcccc}
\hline \multirow{2}{*}{$\begin{array}{l}\text { Storage } \\
\text { period } \\
\text { on days }\end{array}$} & Control & \multicolumn{4}{c}{ Nisin concentration IU/ml } \\
\cline { 2 - 5 } & \multicolumn{4}{c}{ Count CFU/ml } \\
\hline \multirow{nyyyy}{0}{} & $3.1 \times 10^{2} \pm 1.4 \times 10^{2}$ & $2.9 \times 10^{2} \pm 1.4 \times 10^{2}$ & $3.1 \times 10^{2} \pm 1.8 \times 10^{2}$ & $3.30 \times 10^{2} \pm 1.3 \times 10^{2}$ \\
\hline 3 & $6.0 \times 10^{2} \pm 1.6 \times 10^{2}$ & $2.4 \times 10^{2} \pm 8.9 \times 10$ & $2.8 \times 10^{2} \pm 7.6 \times 10$ & $3.0 \times 10^{2} \pm 1.4 \times 10^{2}$ \\
\hline 6 & $5.4 \times 10^{2} \pm 1.1 \times 10^{2}$ & $1.3 \times 10^{2} \pm 7.4 \times 10$ & $2.4 \times 10 \pm 0.4 \times 10$ & $7.1 \times 10 \pm 5.4 \times 10$ \\
\hline 9 & $3.9 \times 10^{2} \pm 0.94 \times 10$ & 00 & 00 & 00 \\
\hline 12 & NT & 00 & 00 & 00 \\
\hline 15 & NT & 00 & 00 & 00 \\
\hline
\end{tabular}

NT: not tested

Means $\pm \mathrm{SE}$ of Ten replications

significant: $P<0.05$ 


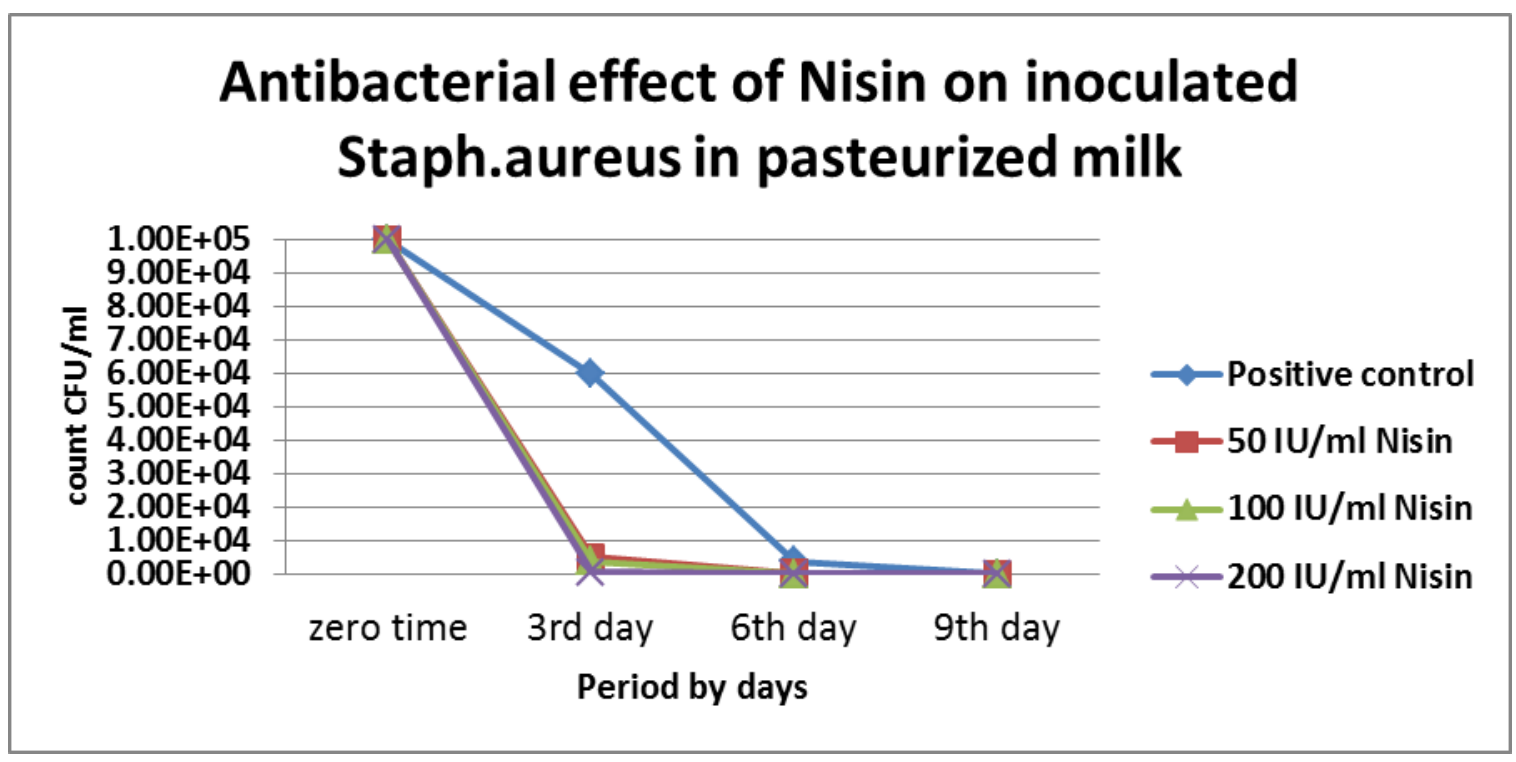

Fig. 1: Antibacterial activity of Nisin on Staph.aureus inoculated in pasteurized milk

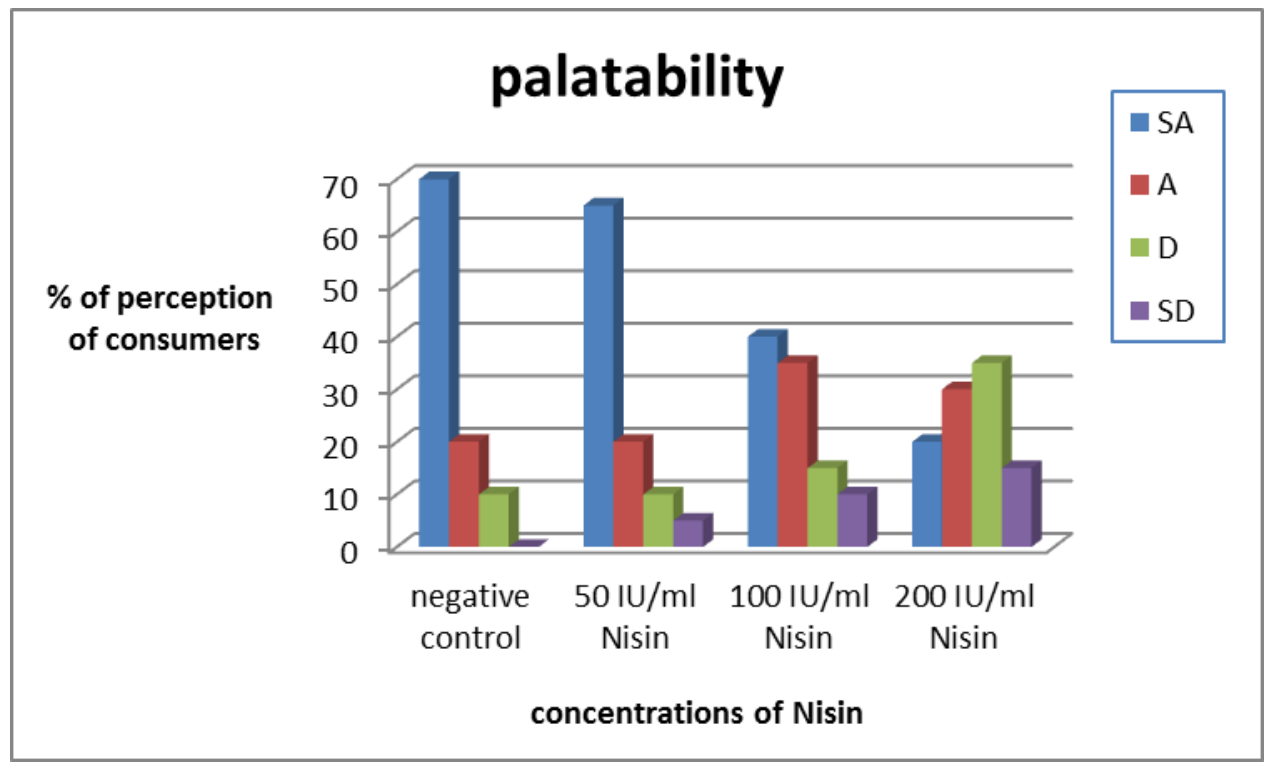

Fig. 2: Palatability of different concentrations of Nisin in pasteurized milk * strongly agree (SA), agree (A), disagree (D), and strongly disagree (SD)

\section{DISCUSSION}

The present study evaluates the efficacy of the nisin at 50, 100 and $200 \mathrm{IU} / \mathrm{ml}$ concentrations in extend the shelf life of pasteurized milk through controlling spoilage bacteria and also, study it's antibacterial activity on Staph. aureus. To carry out this work, we have evaluated the microbial status and $\mathrm{pH}$ of pasteurized milk stored at refrigerator temperature. Also, All the pasteurized milk samples showed negative phosphatase test.

The keeping quality of controlled and nisin added pasteurized milk evaluated by clot on boiling test in table 1 shown that the control samples deteriorated at $9^{\text {th }}$ day while, nisin added samples continued until $16^{\text {th }}$ day irrespective of the level of nisin added. Also, in table 2, the mean $\mathrm{pH}$ of control samples decreased until reached to $3.51 \pm 0.09$ on $15^{\text {th }}$ day while, in nisin added samples slowly decrease in $\mathrm{pH}$ during storage. However, increasing in nisin concentration had no significant effect on $\mathrm{pH}$ in comparison with control ones. An earlier spoilage in control samples could be attributed to the high developed acidity caused by the multiplication of lactic acid bacteria (LAB). In nisin added samples, nisin prevented the multiplication of lactic acid bacteria and thereby delayed the development of 
acidity and prolonged the shelf life (Radha, 2014 and Sarkar, 2016).

Milk is commonly heated to provide stability during storage and assure microbiological safety to consumers. From a hurdle approach, nisin is known to influence the thermal resistance of microorganisms (Penna and Moraes, 2002). Sherif et al. (1994), Olasupo et al. (1996) and Khurana and Kanawjia, (2006) found that gradual decrease in TPC and LAB count for thermized samples added with nisin, they decreased by more than one log cycle and after that there was a gradual decrease in the lactic count of all the samples.

As shown in table 3 nisin reduced the SPC with highly significant effect at $6^{\text {th }}$ day reached to $8.43 \times 10^{2} \pm 2.3 \times 10, \quad 4.40 \times 10^{2} \pm 4.3 \times 10 \quad$ and $4.64 \times 10^{2} \pm 2.0 \times 10$ for 50,100 and $200 \mathrm{IU} / \mathrm{ml}$ nisin concentrations respectively, while, the mean SPC of control samples was $7.15 \times 10^{2} \pm 3.8 \times 10$ on zero day and increased progressively during storage and reached to $1.14 \times 10^{4} \pm 3.9 \times 10^{3}$ at $9^{\text {th }}$ day then samples deteriorated. Wirjantoro et al. (2001) reported no microbial growth in milk treated simultaneously with nisin $(75-150 \mathrm{IU} / \mathrm{mL})$ and heat $\left(117^{\circ} \mathrm{C}\right.$ for $\left.2 \mathrm{~s}\right)$ after storage at 10 or $20{ }^{\circ} \mathrm{C}$ for 1 year. They have also observed that milk treated in this way was easily distinguishable and preferred to a UHT heated control in sensory analysis trials. Plockova et al. (1996) said that addition of nisin at 100 or 500 $\mathrm{mg} / \mathrm{kg}$ suppressed total plate and anaerobic spore counts in processed cheese during 3 months of storage at 5 or $21{ }^{\circ} \mathrm{C}$, and even the growth of Bacillus stearothermophilus, Bacillus cereus and Bacillus subtilis were inhibited by $5 \mathrm{mg} / \mathrm{kg}$ nisin. Also, Wirjantoro and Lewis, (1996) recorded that Log SPC values in the control pasteurized milk samples were increased during storage exceeded than $6.5 \mathrm{cfu} / \mathrm{ml}$ until the samples had spoilt by 14 day. In contrast, the log SPC values in the nisin containing samples remained relatively stable through day 20. The samples containing 40 and 50 IU/ $\mathrm{ml}$ nisin yielded log SPC values of less than 5 at 41 days and had not spoiled by this criterion.

The spoilage bacteria may found to survive after pasteurization, and most of them had the ability to grow under refrigeration storage. So, there is requirement for an effective food preservative for controlling spoilage bacteria in pasteurized milk as nisin (Mitra et al., 2011). Nisin is a heat-stable, cationic, 34-residue polycyclic antibacterial peptide which kills a wide range of spoilage and pathogenic bacteria as it's safe and natural preservative (Schmidt et al., 2009). Table 4 clarified that nisin added samples had highly significant effect on reduce psychrotrophs than control ones specially at $6^{\text {th }}$ day. The mean of psychrotrophs at $6^{\text {th }}$ day were $2.52 \times 10^{3} \pm 4.8 \times 10^{2}, \quad 5.21 \times 10^{2} \pm 1.6 \times 10^{2}, \quad 8.2 \times 10 \pm$ $3.6 \times 10$ and $3.2 \times 10 \pm 1.3 \times 10$ for control, 50, 100 and
200 IU concentrations of nisin, respectively and cannot detected at $12^{\text {th }}$ day for nisin added samples. While, in table 5, the Proteolytic count were $8.33 \times 10^{2} \pm 4.4 \times 10^{2}$ for control samples at zero day and decreased for nisin added samples at $9^{\text {th }}$ day $7.56 \times 10 \pm 3.6 \times 10, \quad 5.23 \times 10 \pm 2.4 \times 10$ and $4.02 \times 10 \pm$ $1.6 \times 10$ for 50,100 and 200 IU concentrations of nisin, respectively until disappeared at $12^{\text {th }}$ day for $200 \mathrm{IU} / \mathrm{ml}$ but control samples were $3.22 \times 10^{3} \pm$ $5.2 \times 10^{2}$ then samples deteriorated. Similar results recorded by Thomas et al., (2000); Kuwano et al. (2005); Mitra et al. (2011) and Ferrocino et al. (2016) but higher result detected by Lee et al. (2015) who can't detect pschrotrophs and proteolytic activity in beef jerky at $2^{\text {nd }}$ day at $100 \mathrm{IU} / \mathrm{ml}$ concentration of nisin and no major change in control samples. Nisin was reported as biopreservative against psychrotrophs in cook-chill foods of soybean sprout, cooked rice, and milk (Vessoni et al., 2002 and Kim et al., 2008). The nisin can decrease the initial cell count of mesophilic bacteria and B.cereus in beef jerky. It's could be an effective approach to extend the shelf life, and improve the microbial safety of beef jerky, during storage (Lee et al., 2015).

Thermophilic count detected at zero time at mean $3.1 \times 10^{2} \pm 1.4 \times 10^{2}$ nearly for all samples (table 6) until $9^{\text {th }}$ day reached to $3.9 \times 10^{2} \pm 0.94 \times 10$ for control samples but can't detected in nisin added samples. The pasteurized milk with nisin was superior in flavour, with no off-flavours within 32 days. Also, no microbial growth could be detected in milk treated simultaneously with nisin $(75-150 \mathrm{IU} / \mathrm{mL})$ and after storage at 10 or $20{ }^{\circ} \mathrm{C}$ for 1 year and, moreover, milk treated in this way was easily distinguishable and preferred to a UHT-heated control in sensory analysis trials (Wirjantoro et al., 2001). The thermophiles are particularly sensitive to nisin, with spores being more sensitive to nisin than vegetative cells. Such an antimicrobial spectrum has resulted in nisin being used as a commercial preservative in products which by their nature cannot be fully sterilized but only pasteurized during their production (Delves-Broughton et al., 1996).

The inhibition of spoilage bacteria and prevention of their regrowth with the nisin helped to extend the shelf life of pasteurized milk by at least 2 months during storage at $8^{\circ} \mathrm{C}$. From the overall findings, it is concluded that the nisin has the potential for use as a backup preservative to counteract postpasteurization contamination in both skim milk and fat milk (Mitra et al., 2011). Consequently, the use of nisin in combination with those heat treatments milk products extended the shelf life of milk, even with poor refrigeration conditions, making possible the substitution of the current thermal treatment for milder treatments and, consequently, better sensory quality (Sobrino-Lo'pez and Martı'n-Belloso, 2008). 
Staph. aureus is the leading cause of a broad range of human infections and associated with food poisoning worldwide. Also, the increasing problem of bacterial resistance to antimicrobials represents the main factor justifying the need to find and develop new antimicrobial agents. Therefore, many researches have focused on naturally derived antimicrobial agents and their characterization (Ozdemir, 2009 and Sudjana et al., 2009). Nisin has been widely used in food industry due to its high potency against certain Gram-positive bacteria, including Staph. aureus (Zhao et al., 2014). Fig. 1 shown complete inhibition of Staph. aureus in nisin added samples at $6^{\text {th }}$ day while, in control samples Staph. aureus could be detected until $9^{\text {th }}$ day in mean count $5 \times 10$. This result in agreement with Cotter et al. (2005); Chalier et al. (2009) and Pinto et al. (2009). While, Dosler and Gerceker, (2012) and Shi et al. (2017) recorded 16 to $32 \mu \mathrm{g} / \mathrm{mL}$ of nisin concentration could be inhibit Staph.aureus within 24h. in pasteurized milk. Pinto et al. (2011) studied that nisin could be inhibit Staph. aureus at concentration 100-500 IU/ml in milk. Nisin can be considered as a natural preservative and is widely used by the food industry and had strong antibacterial activities against Staph. aureus (Shi et al., 2017).

Effect of incorporation of different levels of nisin on palatability scores of pasteurized milk is presented in the fig. $2.65 \%$ of consumers were strongly agree to addition $50 \mathrm{IU} / \mathrm{ml}$ of nisin, while $40 \%$ for $100 \mathrm{IU} / \mathrm{ml}$ and only $20 \%$ for $200 \mathrm{IU} / \mathrm{ml}$ of nisin concentration. These results were agreement with Abdul Hussain et al. (2014); Radha, (2014) and Olasupo et al. (1996) who reported that a Nigerian fermented milk product had acceptable sensory scores till $25^{\text {th }}$ day of its storage when added with nisin at $400 \mathrm{IU} / \mathrm{ml}$. Also, Sobrino-Lo'pez and Marti'n-Belloso, (2008) said that the thermal treatments are known to cause undesirable changes in the sensory, nutritional and/or technological properties of milk. Taking advantage of the antimicrobial action of nisin against several spoilage and pathogenic microorganisms, innovative non-thermal food preservation offer the inactivation of microorganisms with minimal impact on quality and nutritional factors.

From the overall findings reported in this study, it is concluded that the nisin has the potential for use as a bio-preservative to counteract post-pasteurization contamination in pasteurized milk.

\section{REFERENCES}

APHA "American Public Health Association" (1992): Standard Methods for examination of Dairy Products, $15^{\text {th }}$ Ed., New York.

APHA "American Public Health Association" (1998): Standard Methods for examination of
Dairy Products, $20^{\text {th }}$ edn., Washington D.C. USA, 144 and 147-148 pp.

Abdul Hussain, S.; Garg, F.C. and Pal, D. (2014): Effect of different preservative treatments on the shelf-life of sorghum malt based fermented milk beverage. J Food Sci. Technol. 51(8): 1582-1587

Argudin, M.A.; Mendoza, M.C. and Rodicio, M.R. (2010): Food poisoning and Staphylococcus aureus enterotoxins. Toxins (Basel). 2: 17511773.

Bennett, R.W. and Lancette, G.A. (2016): Detection of Staphylococcus aureus in food samples. Bacteriological Analytical Manual (BAM). Ch. 12. https://www. fda.gov/ Food/ FoodScience Research /Laboratory Methods/ucm071429.htm.

Chalier, C.; Cretenet, M.; Even, S. and Le Loir, Y. (2009): Interactions between Staphylococcus aureus and lactic acid bacteria: an old story with new perspectives. International Journal of Food Microbiology, 131, 30-39.

Cotter, P.D.; Hill, C. and Ross, P. (2005): Bacteriocins: developing innate immunity for food. Nature Reviews Microbiology, 3, 777788.

Delves-Broughton, J.; Blackburn, P.; Evans, R.J. and Hugenholtz, J. (1996): Applications of the bacteriocin, nisin. Antonie van Leeuwenhoek 69: 193-202.

Dosler, S. and Gerceker, A.A. (2011): In vitro activities of nisin alone or in combination with vancomycin and ciprofloxacin against methicillin-resistant and methicillinsusceptible Staphylococcus aureus Strains. Chemotherapy. 57, 511-516. doi:10.1159/000335598.

Fasken, J.E. and McClure, A.D. (1940): The Phosphatase Test as an Indicator of Pasteurization of Milk.

FDA /HHS (1988): Direct food substances affirmed as generally recognized as safe: nisin preparation. Fed Reg. 53, 11247-11251.

Ferrocino, I.; Greppi, A.; La Storia, A.; Rantsiou, K.; Ercolini, D. and Cocolina, L. (2016): Impact of Nisin-Activated Packaging on Microbiota of Beef Burgers during Storage. Applied and Environmental Microbiology. 82 (2):549-559

Frank, J.F. and Yousef, A.E. (2004): Thermophilic bacteria. In: Wehr, M.H., Frank, J.F. (Eds.), Standard Methods for the Examination of Dairy Products. American Public Health Association, Washington, DC.230-231.

Gentilini, E.; Denamiel, E.; Llorente, P.; Godaly, S.; Rebulto, M. and De Gregorio, O. (2000): Antimicrobial susceptibility of Staph. aureus isolated from bovine mastitis in Argentina. J. Dairy Sci., 83: 1224-1227.

Gharsallaoui, A.; Oulahal, N.; Joly, C. and Degraeve, P. (2016): Nisin as a Food 
Preservative: Part 1: Physicochemical Properties, Antimicrobial Activity, and Main Uses. Crit Rev Food Sci Nutr. 56(8):1262-74.

Khurana, HK. and Kanawjia, SK. (2006): Extension of shelf-life of mango lassi using biopreservatives. XXXV Dairy Ind. Confererence, November 23-25, Collate, India, DPP No. 02

Kim, H.J.; Lee, N.K.; Lee, D.S.; Hong, W.S.; Lee, S.R.; Kim, C.J. and Paik, H.D. (2008): Improvement of microbiological safety of sous vide processed soybean sprouts: Nisin and Bacillus cereus challenge. Food Sci. Biotechnol. 17, 166-171.

Kindrachuk, J.; Jenssen, H.; Elliott, M.; Nijnik, A.; Magrangeas-Janot, L. and Pasupuleti, M. et al. (2012): Manipulation of innate immunity by a bacterial secreted peptide: lantibiotic nisin $\mathrm{Z}$ is selectively immunomodulatory. Innate Immunity, 19: 1-13.

Kramer, N.E.; Hasper, H.E.; van den Bogaard, P.T.; Morath, S. and de Kruijff, B. et al. (2008): Increased D-alanylation of lipoteichoic acid and a thickened septum are main determinants in the nisin resist 7 ance mechanism of Lactococcus lactis. Microbiology 154: 1755-1762.

Kuwano, K.; Tanaka, N.; Shimizu, T. and Nagatoshi, $K$. (2005): Dual antibacterial mechanisms of nisin $\mathrm{Z}$ against Grampositive and Gramnegative bacteria. Int. J. Antimicrob. Agents. 26: 396-402.

Lee, N.; Kim, H.W.; Lee, J.Y.; Ahn, D.U.; Kim, C. and Paik, H-D. (2015): Antimicrobial Effect of Nisin against Bacillus cereus in Beef Jerky during Storage. Korean J. Food Sci. An. Vol. 35, No. 2, pp. 272-276

Loir, Y.L.; Baron, F. and Gautier, M. (2003): Staphylococcus aureus and food poisoning. Genetics and Molecular Research, 2: 63-76.

López, A. and Belloso, O. (2008): Use of nisin and other bacteriocins for preservation of dairy products. International Dairy Journal, 18 (4): 329-343.

Mitra, S.; Mukhopadhyay, B.C. and Biswas, S.R. (2011): Potential application of the nisin Z preparation of Lactococcus lactis $\mathrm{W} 8$ in preservation of milk. Letters in Applied Microbiology 53: 98-105

Nelson, J.A. and Torut, G.M. (1981): Judging Dairy Products, $4^{\text {th }}$ ed., revised. Westport, CT: The AVC.

Okuda, K.; Zendo, T.; Sugimoto, S.; Iwase, T.; Tajima, A. and Yamada, S., et al. (2013): Effects of bacteriocins on methicillinresistant Staphylococcus aureus biofilm. Antimicrob. Agents Chemother. 57, 55725579. doi:10.1128/AAC.00 888-13.

Olasupo, NA.; Akinsanya, SM.; Oladele, OF. and Azeez, MK. (1996): Evaluation of nisin for the preservation of nono-a Nigerian fermented milk product. J Food Proc Pres 20:71-78.

Ozdemir, Z. (2009): Growth inhibition of Clavibacter michiganensis subsp michiganensis and Pseudomonas syringae pv. tomato by olive mill wastewaters and citric acid. Journal of Plant Pathology, 91, 221-224.

Paterson, R.R.M. and Bridg, P.D. (1994): Biochemical techniques for filamentous fungi. Int. Mycol. Instit. CAB. International Survey, p. 21, UK.

Penna, T.C.V. and Moraes, D.A. (2002): The influence of nisin on the thermal resistance of Bacillus cereus. Journal of Food Protection, 65:415-418.

Pimentel-Filho, Nde J.; Martins, M.C.; Nogueira, G.B.; Mantovani, H.C. and Vanetti, M.C. (2014): Bovicin HC5 and nisin reduce Staphylococcus aureus adhesion to polystyrene and change the hydrophobicity profile and Gibbs free energy of adhesion. International Journal of Food Microbiology, 190: $1-8$.

Pinto, M.S.; Carvalho, A.F.; Pires, A.C.S.; Paula, J.C.J.; Sobral, D. and Magalhães, F.A.R. (2009): Survival of Listeria innocua in Minas traditional Serro cheese during ripening. Food Control, 20, 1167-1170.

Pinto, M.S.; Carvalho, A.F.; Pires, A.C.S.; Souza, A.A.C.; Silva, P.H.F.; Sobral, D.; Paula, J.C.J. and Santos, A.L. (2011): The effects of nisin on Staphylococcus aureus count and the physicochemical properties of Traditional Minas Serro cheese. International Dairy Journal. 21: 90-96.

Plockova, M.; Stepanek, M.; Demnerova, K.; Curda, L. and Svirakova, E. (1996): Effect of nisin for improvement in shelf life and quality of processed cheese. Advances in Food Science, $18,78-83$.

Prado-Acosta, M.; Ruzal, S.M.; Allievi, M.C.; Palomino, M.M. and Rivas, C.S. (2010): Synergistic Effects of the Lactobacillus acidophilus Surface Layer and Nisin on Bacterial Growth. Applied and Environmental Microbiology. 76 (3): 974977.

Radha, K. (2014): Nisin as a biopreservative for pasteurized milk. Ind. J. Vet. and Anim. Sci. Res., 43 (6): 436 - 444.

Sarkar, S. (2016): Effect of Nisin on Technological and Microbiological Characteristics of Stirred Yoghurt. J. Microbiol. Microb. Technol. 1(1): 6.

Schmidt, S.E.; Holub, G.; Sturino, J.M. and Taylor, T.M. (2009): Suppression of Listeria monocytogenes Scott A in fluid milk by free and liposome-entrapped nisin. Probiotics Antimicrob Proteins 1, 152-158.

Sears, P.M.; Smith, B.S.; Stewart, W.K.; Gonzalez, R.N.; Rubino, S.D. and Gusik, S.A., et al. 
(1992): Evaluation of a nisin-based germicidal formulation on teat skin of live cows. J. Dairy Sci. 75, 3185-3190. doi:10.3168/jds.S0022-0302(92)78083-7.

Sharma, J.K.; Malik, R.K. and Mathur, D.K. (2007): Isolation and identification of proteolytic psychrotrophic sporeforming bacteria from raw milk supplies at an experimental dairy in India. Int. J. Dairy Technol. 37, 96-98.

Sherif, S.A.; Hegazi, N.A. and Kandeel, A.A. (1994): Prolongation of yoghurt shelf life using some preservatives. Ann. Agr. Sci-Moshtohor. 32 (1):331-339.

Shi, C.; Zhang, X.; Zhao, X.; Meng, R.; Liu, Z.; Chen, X. and Na Guo (2017): Synergistic interactions of nisin in combination with cinnamaldehyde against Staphylococcus aureus in pasteurized milk. Food Control 71: 10-16.

Sobrino-Lo'pez, A. and Martı'n-Belloso, O. (2008): Use of nisin and other bacteriocins for preservation of dairy products. Review. International Dairy Journal 18: 329-343.

Sudjana, A.N.; D'Orazio, C. and Ryan, V. (2009): Antimicrobial activity of commercial Olea europaea (olive) leaf extract. International Journal of Antimicrobial Agents, 33: 461463.

Thomas, L.V.; Clarkson, M.R. and DelvesBroughton, J. (2000): In A. S. Naidu (Ed.),
Nisin: Natural food antimicrobial systems (Florida, Boca Raton: CRC) Press, 463-524.

Vessoni, P.; Moraes, D.A. and Fajardo, D.N. (2002): The effect of nisin on growth kinetics from activated Bacillus cereus spores in cooked rice and in milk. J. Food Prot. 65, 419-422.

Wiedemann, I.; Benz, R. and Sahl, H.G. (2004): Lipid II-mediated pore formation by the peptide antibiotic nisin: a black lipid membrane study. J Bacteriol 186: 3259-3261.

Wirjantoro, T.I. and Lewis, M.J. (1996): Effect of nisin and high temperature pasteurization on the shelf-life of whole milk. J. of the Society of Dairy Technology. 49 (4): 99-102.

Wirjantoro, T.I.; Lewis, M.J.; Grandison, A.S.; Williams, G.C. and Delves-Broughton, J. (2001): The effect of nisin on the keeping quality of reduced heat-treated milks. J. Food Prot. 64: 213-219.

Wu, J.; Hu, S. and Cao, L. (2007): Therapeutic effect of nisin $\mathrm{Z}$ on subclinical mastitis in lactating cows. Antimicrob. Agents Chemother. 51, 3131-3135.doi: 10.1128/AAC.00629-07.

Zhao, X.C.; Liu, Z.H.; Li, W.L.; Li, X.; Shi, C. and Meng, R.Z.; et al. (2014): In Vitro synergy of nisin and coenzyme $\mathrm{Q}(0)$ against Staphylococcus aureus. Food Control, 46: 368-373.

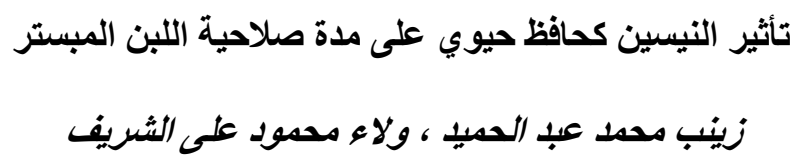

Email: sch_qana@yahoo.com

Assiut University web-site: www.aun.edu.eg

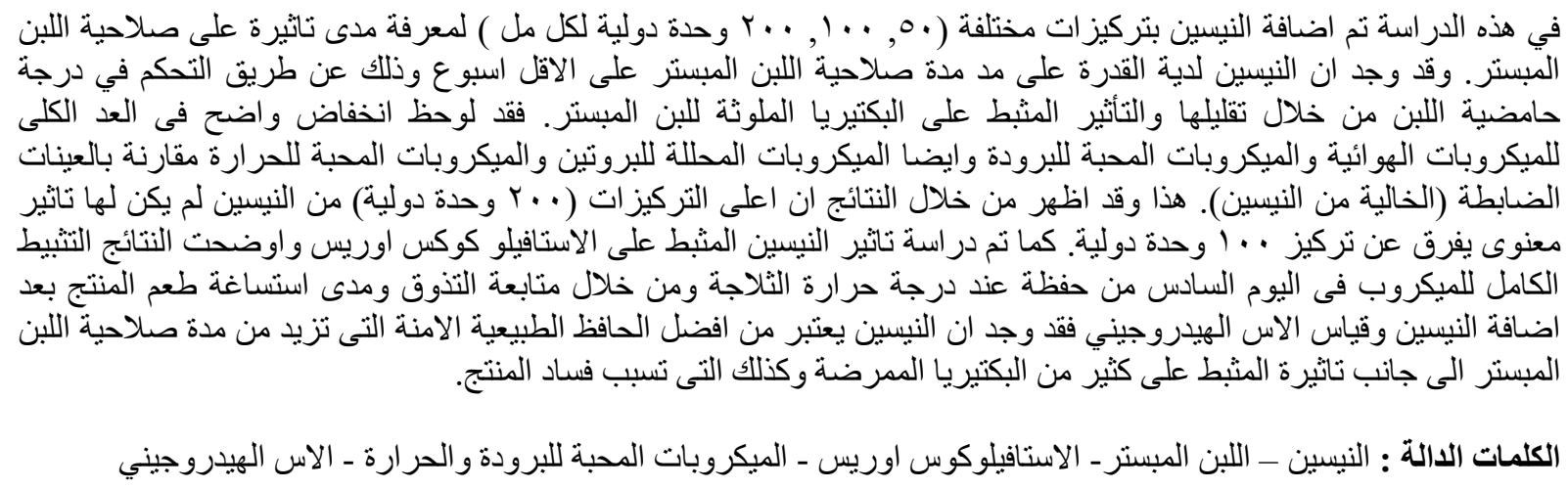

